\title{
An Assessment of Prominent Risks Factors Behind the Development of COVID- I 9 Pandemic Digital Eye Strain in context with the Online Class Room
}

\author{
Anwer Shakeeb K', Naveen H Simon ${ }^{2}$ \\ ${ }^{1}$ Rayhan College \& Hospital, Edapal, Malappuram, Kerala, India. \\ ${ }^{2}$ School of Nursing and Health Sciences NIU, Gautam Budh Nagar, Uttar Pradesh, India. \\ DOI: https://doi.org/10.24321/0019.5138.202142
}

I $\quad \begin{array}{lll}\mathbf{N} & \mathbf{F} & \mathbf{O}\end{array}$

\author{
Corresponding Author: \\ Anwer Shakeeb K, Rayhan College \& Hospital, \\ Edapal, Malappuram, Kerala, India. \\ E-mail Id: \\ anwershakeeb@gmail.com \\ Orcid Id: \\ https://orcid.org/0000-0003-2202-0902 \\ How to cite this article: \\ Anwer Shakeeb K, Simon NH. An Assessment of \\ Prominent Risks Factors Behind the Development \\ of COVID-19 Pandemic Digital Eye Strain in \\ context with the Online Class Room. J Commun \\ Dis. 2021;53(3):80-88.
}

Date of Submission: 2021-06-07

Date of Acceptance: 2021-09-06

\section{$\begin{array}{llllllll}\mathbf{A} & \mathbf{B} & \mathbf{S} & \mathbf{T} & \mathbf{R} & \mathbf{A} & \mathbf{C} & \mathbf{T}\end{array}$}

\begin{abstract}
The COVID-19 outbreak has destructively affected the education system over the world and brought about prominent alterations in the traditional systems of teaching and learning. In order to flatten the curve of disease transmission, several countries have resorted to online classes for students. Apart from the benefits of this strategy, there exists a chance of developing ocular complications in students those are continuously viewed the digital screen without any break. T-test and frequency analysis was used to find out the link between the digital electronic gadgets and eye strains. SPSS version 24.0.0 was used for all the statistical analyses. Here we assessed the various prominent factors behind the development of complications in eyes instigated by the electronic gadgets with special inference on the type of electronic gadgets, time spend, distance, type of usage, kind of posture, light condition, stress, and kind of symptoms towards digital eye strains. One of the major fact that has been emerged in this investigation is that the usage of electronic gadgets for online classes purposes have greatly increased than the other usage. The use of electronic gadgets for work and educational purposes has been recognized as a normal activity among individuals. With the extensive prevalence of developing digital eye strain in the students, it is paramount that the results of this investigation can be used for research purposes as strong research evidence to prevent the complications allied with eyes.
\end{abstract}

Keywords: Digital Eye Strain, Survey Ocular Complaints, Asthenopia, COVID Pandemic, Online Classes, Smartphone

\section{Introduction}

Mandatory e-learning has developed as a prominent strategy for teaching and learning schools, colleges and universities with the footfall of the COVID-19 outbreak. Now it is recognized as a regular routine for students to attend their e-classes using a digital device. That means the new 
e-learning system requires an extra time of sitting in front of digital devices like smartphones or laptops. One of the major facts behind the aforesaid strategy is that there exist no specific guidelines for e-learning. 3,23,27

Spending much more time with such devices than the normal level can result in ocular problems. Specifically, the digital devices that are used for the abovesaid aspects can cause adverse effects to the individuals since these kinds of digital devices has been previously reported to emit high energy waves that can have the ability to penetrate the eyes. ${ }^{3,12}$ Altogether, digital eye strain (DES) is the principal term used to illustrate problems allied with the eye (blurring of vision, itching, watering, headaches and dry eyes) in response to the prolonged use of the digital device. That means, all the facts have directed us to direct towards the prominent use of various electronic gadgets that have extensive significance in the current scenario due to the massive growth in digital device technology as well as on the internet. A study by Rosenfield $M$ indicated that a plethora of factors are thought to contribute to digital eye strain, and it has been reported that a combination of symptom-instigating factors may augment the magnitude of symptoms. ${ }^{24}$ Dry eye is recognized as the significant threat of digital eye strain along with other factors such as environmental influences, altered blinking characteristics and gaze angle considered significant to dryness with prominent digital device use. The inappropriate surrounding condition with and airborne dust/toner particles, air conditioning and low humidity ventilation fans may also augment the chance for corneal drying. ${ }^{4}$ Moreover, the light exposure is also recognized as the main contributing factor in developing eye complications (Liesegang, 2002). A study by Moon JH et al. from South Korea have reported that the use of digital screen with long duration may develop risk factors linked for digital eye strain. ${ }^{20}$ Termination of smartphone use for a (4-week) particular period have resulted in prominent improvement. 20 The longer duration followed by less intense light exposure may instigate photochemical damage also. ${ }^{29}$ Certain previous studies have reported the significance of studying the various factors that influences the development of digital eye strains interconnected to dry eye. ${ }^{22}$

Coming back to the report from 2013, it was found that the shipment of laptopordesktop has massively increased from 200 million units (2005) to 400 million units (2013). ${ }^{5}$ Likewise, the smartphone shipment has also increased to 800 million units (2013) from 100 million units (2005). In context with the aforementioned facts, it is found that one of the major reasons for the prevalence of DES was the augmented use of electronic gadgets. ${ }^{25}$

In order to answer the questions on the prominent impacts of electronic gadgets on DES, several previous investigations have used questionnaires that included the electronic gadgets and health problems. 8 Therefore the present investigation was undertaken to estimate the chance of developing DES among students of taking online classes along with predicting the risk factors behind the DES in context with the type of electronic gadgets, how many hours spend, distance, type of usage, kind of posture, light condition, stress, and kind of symptoms of DES.

\section{Materials and Methods}

\section{Survey}

The questionnaire-based study was undertaken between April and May 2021. This study was approved by the Institutional ethics committee of Al Rayhan Group of Institutions, Rayhan College \& Hospital, Edapal, Malappuram, Kerala, India Kerala, India (RREC/2021/0110).

\section{Eligibility Criteria and Survey protocol}

The present study has included students of Rayhan College, Edapal; Rayhan College, Triprayar; Rayhan College, Kondoty; and Rayhan College, Tirur. The electronic devices included in the list for analysis are Desktop computers, laptops and smartphones. The participants in this study ranged in age from 18 to 21 years. This includes males and females only. An anonymous, self-administered questionnaire in English was developed through Google Forms using the English language as the primary subject. The link to participate in the survey was sent through email and each student was updated regarding the investigation in detail and digital consent was obtained before the survey.

\section{Questionnaire Design and Statistics}

An online questionnaire for the survey was generated by the authors which is composed of the following sections as enlisted in Annexure 1. The data regarding the Digital Eye Strain from the questionnaires were pooled in MS Office Excel 2019 and exported into SPSS version 24.0.0. T-test, frequency analysis and paired samples test (T-paired) were used to find out the link between digital electronic gadgets and eye strains. The paired values were significant at $\mathrm{P}<0.05$.

\section{Results}

\section{Demographic Profile}

The present investigation has analyzed the prominent impact of electronic gadgets in eye strain using the questionnaire data from 489 students from the Rayhan College, Edapal; Rayhan College, Triprayar; Rayhan College, Kondoty; and Rayhan College, Tirur. All the students who participated in the survey used English as the primary language ( $\mathrm{n}=$ $489,100 \%)$. 
Table I.Demographic Profile of the Students

\begin{tabular}{|c|c|}
\hline Age & $\begin{array}{c}\mathbf{1 9 . 5 2} \pm \mathbf{1 . 4 7} \\
\text { (Mean } \pm \text { SD) }\end{array}$ \\
\hline Students from Rayhan College, Kondoty & $25.36 \%$ \\
\hline Students Rayhan College, Edapal & $49.69 \%$ \\
\hline Students Rayhan College, Tirur & $4.09 \%$ \\
\hline Students Rayhan College,Triprayar & $20.86 \%$ \\
\hline Participants using spectacles & \\
\hline No vision related issues identified & 72.4 \\
\hline $\begin{array}{c}\text { Vision related issues are there but not } \\
\text { using spectacles }\end{array}$ & 12.3 \\
\hline Yes & 15.3 \\
\hline
\end{tabular}

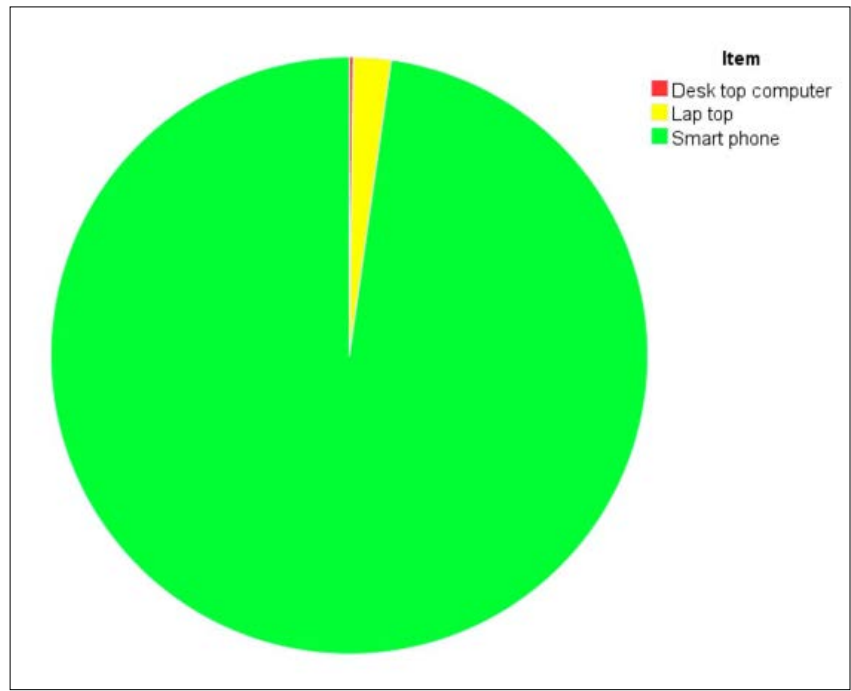

Figure I.Digital Devices using for Online Class

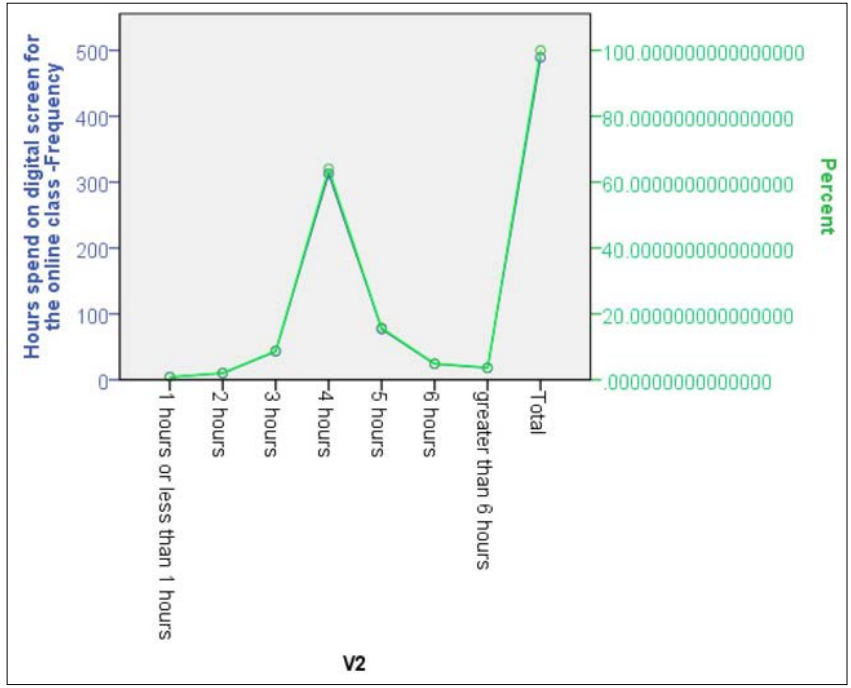

Figure 2.Hours Spend on Digital Screen for the Online Class

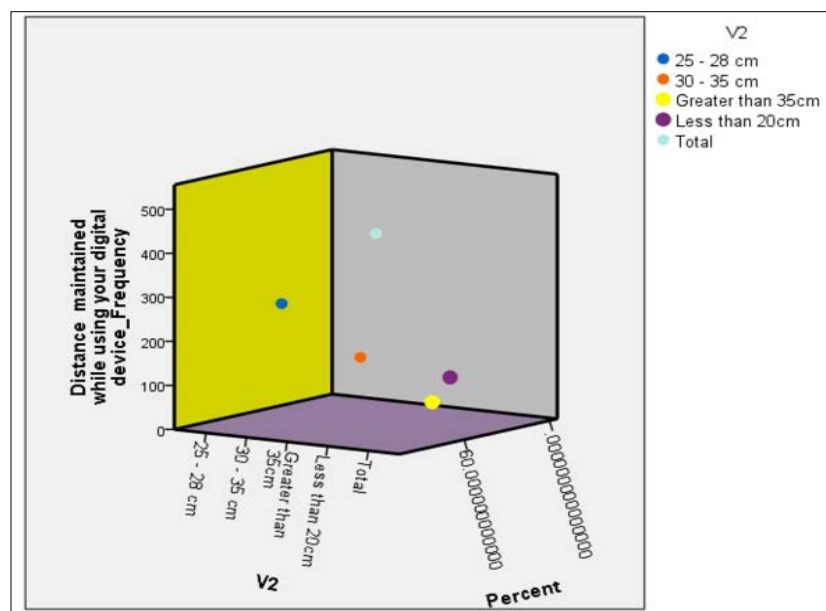

Figure 3.Distance Maintained while using Digital Devices Digital Device and Type of Usage Pattern

The statistical analysis clearly illustrates that the most common electronic gadget which is used for the online classroom was the smartphone $(97.8 \% ; n=478)$ with a $t$ value of $1.03(0.04) \quad(P<0.05 ; 0.041 ; d f-2)$. One of the major facts is that among the 489 participants only $0.2 \%$ and $2 \%$ of students have used Desktop computers and Laptops for online classes (Figure 1). It indicates that the complications observed in the candidates are primarily instigated by the electronic gadget smartphone $(P<0.05$; 0.041 ;f - 2). As illustrated in Figure 2, about $64 \%$ of the participants have spent 4 hours for an online class ( $t-1.92$; $\mathrm{P}<0.05 ; 0.01 ; \mathrm{df}-7)$. Only $15.7 \%$ and $4.9 \%$ of the students have spent 5 and 6 hours for online class purposes. It was clearly evident that the candidates those are frequently used electronic gadgets without any proper preventive measures have faced the following major complications; blurred vision, neck and shoulder pain, dry eyes, eyestrain, headache $(t-1.98 ; P<0.05 ; 0.005 ; \mathrm{df}-2.8)$.

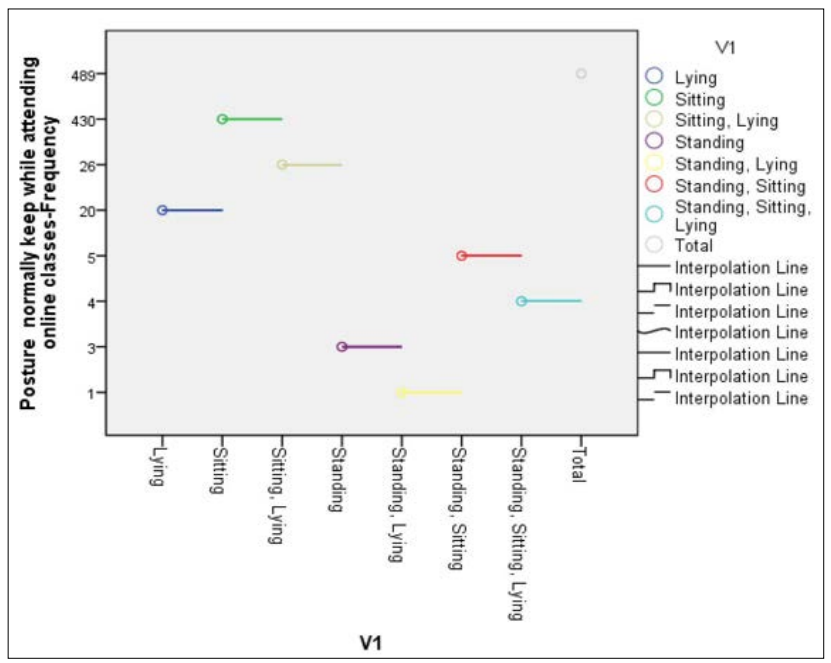

Figure 4.Posture Keep while Attending Online Classes 
The statistical analysis also revealed that only $0.8 \%$ of students are spent 1 hour for the same purpose. As another point that has been emerged as significant in this investigation is that about $45 \%$ of the total population have spent only less than 4 hours with electronic gadgets for other purposes (apart from online classes) ( $t-2.46$; $P$ $<0.05$; 0.006; $\mathrm{df}-4$ ). This has indicated the fact that the usage of electronic gadgets for online class rather than other purposes has greatly increased from four hours to six hours for the online class ( $t-1.92 ; P<0.05 ; 0.01 ; d f-7)$. Such kinds of activities have usually resulted in the development of severe clinical complications including blurred vision, neck and shoulder pain, eyestrain and headache. Among the various complications faced by the candidates those are regularly use the electronic gadget for more than four hours to six hours, the eyestrain and headache are considered as the most common significant complications ( $\mathrm{t}-1.32 ; \mathrm{P}<0.05 ; 0.01 ; \mathrm{df}-7)$. With so many people using four, to six hours, it is important to investigate the posture and distance maintained in front of the digital screen. As depicted in Figure 3 it was found that there exists a pattern in $52.1 \%$ of participants ( $t-2.36$; $P<0.05 ; 0.008$; $d f-4$ ) to maintain $25-28 \mathrm{~cm}$. in agreement with the pattern of these participants, about $25.4 \%$ have maintained $30-35$ $\mathrm{cm}$ during online classes. The remaining $19.2 \%$ and $3.3 \%$ of the students are known to maintain less than $20 \mathrm{~cm}$ and greater than $35 \mathrm{~cm}$ respectively indicating the chance of developing digital eye strains. The neck and shoulder pain has been observed as the prominent complications found in such circumstances ( $t-1.52 ; P<0.05 ; 0.01 ; d f-7)$. While the authors have investigated the significance of the type of posture which would maintain by the students in front of the digital screen, it was evident that about $87.9 \%$ ( $t$ 1.65; $P<0.05 ; 0.01 ; \mathrm{df}-7$ ) of the participants are likely to choose sitting while attending the online classes. As depicted in Figure 4, only $4.1 \%$ of the participants used lying as a prominent posture while attending the class.

\section{Probable Risk Factors and Symptoms}

From the author's point of view, light sensitivity has played an important role in developing minor irritations to serious medical emergencies in the eyes. As for the reason that this investigation investigated the aforementioned aspect and revealed that about $57.9 \%$ of participants maintained bright light during electronic gadget use while $32.3 \%$ of students use dark light. The continuous use of the electronic gadget with higher or very low light has instigated severe complications including eye strain, headache and dry eyes ( $t-2.58 ; P<0.05 ; 0.008 ; d f-3$ ). One of the important things that have been noted in this part of the study was $9.8 \%$ of the participants had used their electronic gadgets without any light. They have also faced the threat of eye strain and headache ( $t-0.98 ; P<0.05 ; 0.003 ; \mathrm{df}-7$ ).
Most of the participants (63.4\%; $\mathrm{t}-2.39 ; \mathrm{P}<0.05 ; 0.009$; $\mathrm{df}$ - 3) maintained their height as below eye level during the online class. The candidates those are maintained the height above and below eye level have faced certain kinds of complications including eyestrain, neck and shoulder pain ( $\mathrm{t}-1.47 ; \mathrm{P}<0.05 ; 0.001 ; \mathrm{df}-7$ ). Collecting the data altogether, it is essential to investigate the type of usage of the electronic gadgets to get a clear picture regarding the view of each participant in preventing digital eye strains.

From the data, it was clearly illustrated a picture that reveals $85.7 \%(\mathrm{t}-2.51 ; \mathrm{P}<0.05 ; 0.01 ; \mathrm{df}-2$ ) of the participants had taken a break in between hours while attending the online class. However, $14.35 \%$ ( $y=1.14 \mathrm{E}-13+4.89 * x)$ of the students are may be unaware of the critical complications that have been emerged from the aforementioned risks since they have completed their online class within a single stretch. The severe complications instigated by the single stretch use have included eyestrain, headache, blurred vision, dry eyes, neck and shoulder pain ( $\mathrm{t}-1.01$; $\mathrm{P}<0.01$; $0.001 ; \mathrm{df}-7)$.

Table 2.Symptoms while Using your Digital Screen

\begin{tabular}{|c|c|c|}
\hline Symptoms & Frequency & Percent \\
\hline Blurred vision & 2 & 0.4 \\
\hline $\begin{array}{l}\text { Blurred vision, Neck and } \\
\text { shoulder pain }\end{array}$ & 1 & 0.2 \\
\hline Blurred vision, No symptoms yet & 1 & 0.2 \\
\hline Dry eyes & 4 & 0.8 \\
\hline $\begin{array}{c}\text { Dry eyes, Neck and shoulder } \\
\text { pain }\end{array}$ & 4 & 0.8 \\
\hline Eyestrain & 40 & 8.2 \\
\hline Eyestrain, Blurred vision & 5 & 1.0 \\
\hline $\begin{array}{l}\text { Eyestrain, Blurred vision, Neck } \\
\text { and shoulder pain }\end{array}$ & 1 & 0.2 \\
\hline Eyestrain, Dry eyes & 6 & 1.2 \\
\hline $\begin{array}{c}\text { Eyestrain, Dry eyes, Neck and } \\
\text { shoulder pain }\end{array}$ & 3 & 0.6 \\
\hline Eyestrain, Headache & 37 & 7.6 \\
\hline $\begin{array}{c}\text { Eyestrain, Headache, Blurred } \\
\text { vision }\end{array}$ & 3 & 0.6 \\
\hline $\begin{array}{l}\text { Eyestrain, Headache, Blurred } \\
\text { vision, Dry eyes, Neck and } \\
\text { shoulder pain }\end{array}$ & 2 & 0.4 \\
\hline $\begin{array}{l}\text { Eyestrain, Headache, Blurred } \\
\text { vision, Neck and shoulder pain }\end{array}$ & 4 & 0.8 \\
\hline Eyestrain, Headache, Dry eyes & 4 & 0.8 \\
\hline $\begin{array}{l}\text { Eyestrain, Headache, Dry eyes, } \\
\text { Neck and shoulder pain }\end{array}$ & 10 & 2.0 \\
\hline
\end{tabular}




\begin{tabular}{|c|c|c|}
\hline $\begin{array}{c}\text { Eyestrain, Headache, Neck and } \\
\text { shoulder pain }\end{array}$ & 51 & 10.4 \\
\hline $\begin{array}{c}\text { Eyestrain, Neck and shoulder } \\
\text { pain }\end{array}$ & 15 & 3.1 \\
\hline $\begin{array}{c}\text { Eyestrain, No symptoms yet } \\
\text { Headache }\end{array}$ & 1 & 0.2 \\
\hline Headache, Blurred vision & 2 & 13.5 \\
\hline $\begin{array}{c}\text { Headache, Blurred vision, Neck } \\
\text { and shoulder pain }\end{array}$ & 7 & 1.4 \\
\hline Headache, Dry eyes & 7 & 1.4 \\
\hline $\begin{array}{c}\text { Headache, Dry eyes, Neck and } \\
\text { shoulder pain }\end{array}$ & 1 & 0.2 \\
\hline $\begin{array}{c}\text { Headache, Neck and shoulder } \\
\text { pain }\end{array}$ & 45 & 9.2 \\
\hline Headache, No symptoms yet & 2 & 0.4 \\
\hline Neck and shoulder pain & 46 & 9.4 \\
\hline No symptoms yet & 119 & 24.3 \\
\hline Total & 489 & 100.0 \\
\hline
\end{tabular}

Table 3.Preventive Measures for Eye

\begin{tabular}{|c|c|c|}
\hline Preventive measures & Frequency & Percent \\
\hline $\begin{array}{c}\text { Doing blinking exercise regularly } \\
\text { Doing blinking exercise regularly, } \\
\text { I am aware about it but not } \\
\text { following such preventive } \\
\text { methods }\end{array}$ & 25 & 3.1 \\
\hline $\begin{array}{c}\text { Doing blinking exercise regularly, } \\
\text { Keeping proper lighting and } \\
\text { sitting posture while attending } \\
\text { the classes }\end{array}$ & 4 & 0.4 \\
\hline $\begin{array}{c}\text { Doing blinking exercise regularly, } \\
\text { Proper break is taking in } \\
\text { between classes }\end{array}$ & 9 & 1.8 \\
\hline $\begin{array}{c}\text { Doing blinking exercise } \\
\text { regularly, Proper break is taking } \\
\text { in between classes, I am aware } \\
\text { about it but not following such } \\
\text { preventive methods }\end{array}$ & 1 & 0.2 \\
\hline $\begin{array}{c}\text { Doing blinking exercise } \\
\text { regularly, Proper break is taking } \\
\text { in between classes, Keeping } \\
\text { proper lighting and sitting } \\
\text { posture while attending the } \\
\text { classes }\end{array}$ & 13 & 2.7 \\
\hline $\begin{array}{c}\text { I am aware about it but not } \\
\text { following such preventive } \\
\text { methods }\end{array}$ & 138 & 28.2 \\
\hline
\end{tabular}

\begin{tabular}{|c|c|c|}
\hline $\begin{array}{l}\text { I am not aware about it and } \\
\text { not following such preventive } \\
\text { methods }\end{array}$ & 58 & 11.9 \\
\hline $\begin{array}{l}\text { Keeping proper lighting and } \\
\text { sitting posture while attending } \\
\text { the classes }\end{array}$ & 77 & 15.7 \\
\hline $\begin{array}{l}\text { Keeping proper lighting and } \\
\text { sitting posture while attending } \\
\text { the classes, I am aware about } \\
\text { it but not following such } \\
\text { preventive methods }\end{array}$ & 2 & 0.4 \\
\hline $\begin{array}{l}\text { Keeping proper lighting and } \\
\text { sitting posture while attending } \\
\text { the classes, I am not aware } \\
\text { about it and not following such } \\
\text { preventive methods }\end{array}$ & 1 & 0.2 \\
\hline $\begin{array}{c}\text { Proper break is taking in } \\
\text { between classes }\end{array}$ & 100 & 20.4 \\
\hline $\begin{array}{c}\text { Proper break is taking in } \\
\text { between classes, I am aware } \\
\text { about it but not following such } \\
\text { preventive methods }\end{array}$ & 7 & 1.4 \\
\hline $\begin{array}{l}\text { Proper break is taking in } \\
\text { between classes, I am not aware } \\
\text { about it and not following such } \\
\text { preventive methods }\end{array}$ & 1 & 0.2 \\
\hline $\begin{array}{l}\text { Proper break is taking in } \\
\text { between classes, Keeping } \\
\text { proper lighting and sitting } \\
\text { posture while attending the } \\
\text { classes }\end{array}$ & 27 & 5.5 \\
\hline $\begin{array}{l}\text { Proper break is taking in } \\
\text { between classes, Keeping } \\
\text { proper lighting and sitting } \\
\text { posture while attending the } \\
\text { classes, I am aware about it but } \\
\text { not following such preventive } \\
\text { methods }\end{array}$ & 1 & 0.2 \\
\hline $\begin{array}{l}\text { Using anti reflective coated } \\
\text { spectacle or digital screen }\end{array}$ & 15 & 3.1 \\
\hline $\begin{array}{c}\text { Using anti reflective coated } \\
\text { spectacle or digital screen, } \\
\text { Doing blinking exercise regularly }\end{array}$ & 3 & 0.6 \\
\hline $\begin{array}{l}\text { Using anti reflective coated } \\
\text { spectacle or digital screen, } \\
\text { Doing blinking exercise regularly, } \\
\text { Keeping proper lighting and } \\
\text { sitting posture while attending } \\
\text { the classes }\end{array}$ & 1 & 0.2 \\
\hline
\end{tabular}




\begin{tabular}{|c|c|c|}
\hline $\begin{array}{l}\text { Using anti reflective coated } \\
\text { spectacle or digital screen, } \\
\text { Doing blinking exercise regularly, } \\
\text { Proper break is taking in } \\
\text { between classes }\end{array}$ & 1 & 0.2 \\
\hline $\begin{array}{l}\text { Using anti reflective coated } \\
\text { spectacle or digital screen, } \\
\text { Doing blinking exercise } \\
\text { regularly, Proper break is taking } \\
\text { in between classes, I am aware } \\
\text { about it but not following such } \\
\text { preventive methods }\end{array}$ & 1 & 0.2 \\
\hline $\begin{array}{l}\text { Using anti reflective coated } \\
\text { spectacle or digital screen, } \\
\text { Doing blinking exercise } \\
\text { regularly, Proper break is taking } \\
\text { in between classes, Keeping } \\
\text { proper lighting and sitting } \\
\text { posture while attending the } \\
\text { classes }\end{array}$ & 1 & 0.2 \\
\hline $\begin{array}{l}\text { Using anti reflective coated } \\
\text { spectacle or digital screen, I am } \\
\text { aware about it but not following } \\
\text { such preventive methods }\end{array}$ & 3 & 0.6 \\
\hline $\begin{array}{c}\text { Using anti reflective coated } \\
\text { spectacle or digital screen, } \\
\text { Proper break is taking in } \\
\text { between classes }\end{array}$ & 5 & 1.0 \\
\hline $\begin{array}{l}\text { Using anti reflective coated } \\
\text { spectacle or digital screen, } \\
\text { Proper break is taking in } \\
\text { between classes, Keeping } \\
\text { proper lighting and sitting } \\
\text { posture while attending the } \\
\text { classes }\end{array}$ & 3 & 0.6 \\
\hline Total & 489 & 100.0 \\
\hline
\end{tabular}

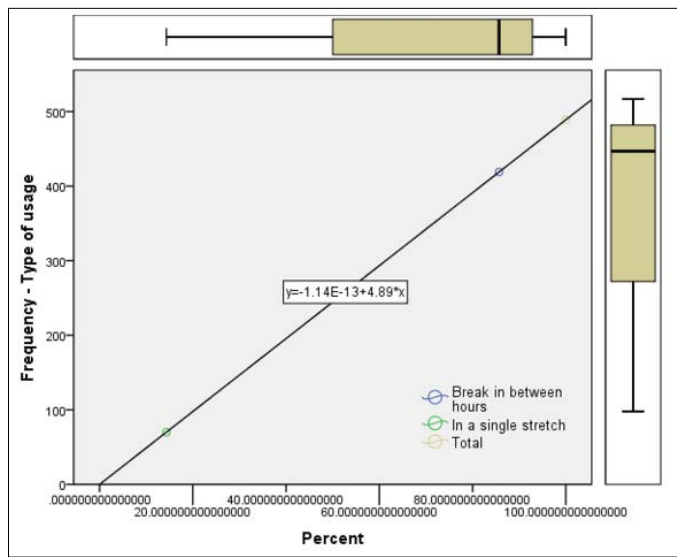

Figure 5.Type of Usage of Electronic Gadgets in Online Class
In addition, there may be individual interest may happen in such participants to complete their online schedule (Figure 5). In agreement with these findings, the data analysis regarding the spectacle use has revealed that $15.3 \%$ ( $t-2.30 ; P<0.05 ; 0.01 ; \mathrm{df}-3)$ of the students have faced vision-related complications. In order to overcome the threatening effects, the aforesaid participants have used the applicability of spectacles in their life $(t-2.30$; $P<0.05 ; 0.01 ; \mathrm{df}-3)$. In addition to this, another thing that has been found in this section is that about $12.3 \%$ of the students don't use the applicability of spectacles in their life. The present investigation has also analyzed the abovementioned risk factors towards the development of digital eye strain. As enlisted in Table 2, only $24.3 \%$ of the total population had free from the critical problems, while the $75 \%$ of the participants are known to possess various severe complications including blurred vision, neck and shoulder pain, eyestrain and headache $(\mathrm{t}-1.98 ; \mathrm{P}<$ $0.05 ; 0.005 ; \mathrm{df}-2.8)$. The concept of $28.2 \%$ of the students regarding the developments of eye strain was noted as a prominent factor in this investigation since they are aware of the aforesaid severe complications but not following such preventive methods. However, $59.90 \%$ of the participants are reported to be vigilant in preventing the complications in the eye instigated by the electronic gadgets (Table 3 ) ( $t$ - 1.94; $P<0.05 ; 0.03 ; \mathrm{df}-2.5$ ).

\section{Discussion}

Due to the rapid spread of COVID-19 worldwide, the central government and state government have decided to shut down the schools to break the chain of the deadly virus responsible for COVID-19. It had affected the education of more than 1.5 billion students worldwide illustrating the need of developing alternative strategies to overcome such a drastic situation. From here the scientific community, various national and international agencies, and government suggest the possibility of implementing the online e-learning system for students.18 However, the long before the COVID-19 pandemic, the scientific community reported the discrepancy allied with the improvements and promises brought by the technology of education. 28

After the suggestion by the governmental and nongovernmental agencies, the educational institutions and teachers have explored the available digital tools to ensure teaching and learning. A recent investigation revealed that about $70 \%$ of the young generation worldwide used smartphones or mobile phones as a primary electronic gadget for internet use during this coronavirus outbreak period. A similar pattern has been observed in this study since $97.8 \%$ percentage of the participants have used smartphones for online classes.

The present investigation has assessed the various prominent factors behind the development of complications in eyes 
instigated by the electronic gadgets with special inference on the type of electronic gadgets, time spend, distance, type of usage, kind of posture, light condition, stress, and kind of symptoms towards digital eye strains. One of the major fact that has been emerged in this investigation is that the usage of electronic gadgets for online classes purposes have greatly increased than the other usage. In addition to this, the present investigation also reported the habit of not taking enough breaks during digital screen viewing. In agreement with our findings, an investigation by Ganne $P$ et al.7 verified the aforesaid perspectives and reported that the use of electronic gadgets for online classes has been increased in the current COVID-19 scenario.

A study by Mohan A et al.18 revealed that smartphone is recognized as the foremost electronic gadgets which were used for online classes ( $n=134,61.7 \%$ ). The present investigation has strongly agreed with the aforementioned perspectives by revealing the fact that about $97.8 \%$ percentage of the participants used smartphones for the online class purpose $(n=478)$ with a t value of $1.03(0.04)$ $(P<0.05 ; 0.041 ; d f-2)$. Based on the results of this study along with the previous investigation it was prominently reported that the majority of the participants preferred to use a smartphone for the online class. Previous studies have verified the digital device prompted complications in human populations. $6 \mathrm{~A}$ recent study has discussed the same pattern as seen in the present investigation. ${ }^{1}$ According to them the most common type of threat linked with digital eye strain includes pain in the neck and shoulders, blurred vision, eyestrain, and headaches are considered as the prominent kinds of complications instigated by the frequent and regular use of digital devices like smartphone and computers. The present investigation have unveiled the same pattern as discussed by them, which justifying the significance of the findings in the current scenario. Another investigation has also reported the following complications instigated by the frequent use of digital devices; blurred vision, dry eyes, eyestrain, headaches, pain in the neck and shoulders. ${ }^{26}$

Apart from the benefits of the online learning system, it is essential to discuss the various factors that influence the development of complications in the eye of students. For instance, verified that the extensive use of smartphones resulted in a number of ocular complications ranges from irritation, conjunctival injection, burning sensation, strain to myopia. ${ }^{19,31}$ Moreover, they also reported that the chance of developing symptoms of dry eye diseases was increased in the individuals who are spending more hours with the smartphone. The results of this investigation have witnessed that the duration of electronic gadgets uses primarily increased among the participants in the COVID 19 scenario. The continuous smartphone uses results in a reduced blink rate thereby causing ocular complications in the suspected individuals. ${ }^{9,18}$ The prolonged use of electronic gadgets including the computer and smartphones have also corresponded with certain ocular complaints including the eyes feeling heavy and itchy eyes followed by pain in/ around the eyes. ${ }^{13,16}$ We have found the almost same kind of ocular complications in the studied individuals. Viewing digital screens within a short distance has been known to be recognized as a principal factor behind the development of asthenopia symptoms in individuals. ${ }^{15}$ Here we need to analyze the probable benefits regarding the extensive use of smartphones within a short distance.

The physical dimensions of the display of smartphones are usually smaller than laptop and desktop computers. Most of all the websites provide the smartphone-friendly data with small font size and which allows the users to hold the smartphone at a short distance. ${ }^{2}$ When the font size is smaller, the chance of developing difficulty for visual task search is augmented. ${ }^{11}$ Based on the results of this investigation along with the previous literature it was prominently reported that it is essential to maintain proper guidelines while viewing the digital screen. Moreover, reducing the duration of electronic gadgets like smartphones by taking a "break" can be reported as a significant way to diminishes ocular complications. The diminishing blink rate with frequent electronic gadget use may result in dry eye symptoms. In agreement with their findings, the present investigation has verified the same perspective since the individuals those are primarily use the electronic gadgets in a single stretch have primarily been threatened by dry eye symptoms and other complications linked with the eye..$^{21,26}$ Patel et al. ${ }^{21}$ have also reported certain eye complications along with the activities and are; blurred vision when looking into the distance, blurred vision viewing the computer, difficulty or slowness in refocusing my eyes from one distance to another, dry eyes, tired eyes, eye discomfort, headache, eye strain. The fact is that most of the complications have also been enlisted in the present investigation. The 20/20/20 rule has been known to reduce the various symptoms of asthenopia while viewing the digital screen. Previous literature has suggested taking a break for 20 seconds while viewing the digital screen. ${ }^{17}$ Another major factor that has been found in both the literature10 and in this study is that the participants tend to implement inappropriate posture which can be responsible for musculoskeletal alterations and pain. This is a disturbing context since the students are threatened by the risk factors which may result in musculoskeletal pain and is being responsible for interfering with the health and quality of future professionals. Moreover, the room light condition and the height maintained while viewing the digital screen has also significant impact on the ocular complications.

As mentioned in the former sections, the ubiquitous exposure to electronic gadgets and the digital screen has 
opened the way to raise questions concerning the drastic adverse effects linked with the eye. As reported by Loh K, Redd S, ${ }^{14}$ such habitats develop shoulder-neck pain, lower back pain, (61.4\%), and other stress-related complications associated with eye strain (70.6\%). Loh $\mathrm{K}$, Redd $\mathrm{S}^{14}$ verified that various following pathophysiological mechanisms along with the ocular complications; Extraocular (neck stiffness, neck pain, shoulder pain, headache, backache), Ocular surface (tearing, gritty, dryness, redness, gritty, sensation burning), Accommodative mechanism (blurring of vision) and related patterns (double vision, presbyopia, myopia, slowness of focus change). As enlisted in Table 2 , In agreement with their findings, the present investigation has reported the various complications while using the digital screen. In order to overcome the threatening effects of ocular complications previous studies have suggested the possibility of implementing various strategies as enlisted listed in Table 3. Concentrating on a particular entity in a digital screen is often inhibits the blinking, thereby the eye tends to generate more amount of tear evaporation. ${ }^{14}$ Moreover, there exists a prominent positive link between eye-related pain, orbicularis oculi muscle load and muscle blood flow. The eye exercises can offer better relief in strain and pain. ${ }^{14}$ From the abovesaid perspectives and facts, it was analyzed that the poor lighting, screen brightness, improper posture, type of usage, duration of electronic gadgets use have a prominent impact in developing the eye strain. Therefore, the present investigation has suggested that sufficient blinking along with the execution of eye exercise and the use of spectacles including self-eye care using latest technology may definitely assists to relive the eye complications.

\section{Conclusion}

The use of advanced electronic gadgets and technologies gave new heights to success and saves time however, an array of health-linked hazardous and complications have been recognized as the by-product of the same. Augmented use of electronic gadgets like smartphones, which is principally found as the primary device for $97.8 \%$ of the participants in this study, has increased the rate of a number of individuals with digital eye strains. Digital eye strain symptoms are known to emerge in two ways; 1) external symptoms - dry eye and 2) internal symptoms associated with accommodation or vergence problems and ametropia. In view of the abovementioned facts, this study analyzed the various factors responsible for the development of complications in eyes instigated by the electronic gadgets with special inference on the type of electronic gadgets, time spend, distance, type of usage, kind of posture, light condition, stress, and kind of symptoms towards digital eye strains. The results and discussions that emerged in this study clearly illustrate that working more time with electronic gadgets especially with smartphones can cause ocular complaints among students. Keeping level of eyes above the digital screen, maintaining ideal distance from the screen, using antiglare screen, taking frequent breaks can be recognized as the principal factor in reducing the digital eye strains.

\section{Conflict of Interest: None \\ References}

1. American Optometric Association. Computer vision syndrome. 2017. Available from: https://www.aoa. org/healthy-eyes/eye-and-vision-conditions/computervision-syndrome?sso=y.

2. Bababekova Y, Rosenfield M, Hue JE, Huang RR. Font size and viewing distance of handheld smart phones. Optom Vis Sci. 2011 Jul;88(7):795-7. [PubMed] [Google Scholar]

3. Bhattacharya S, Saleem SM, Singh A. 2020. Digital eye strain in the era of COVID-19 pandemic: An emerging public health threat. Indian J Ophthalmol. 2020 Aug;68(8):1709-10. [PubMed] [Google Scholar]

4. Blehm C, Vishnu S, Khattak A, Mitra S, Yee RW. Computer vision syndrome: a review. Surv Ophthalmol. 2005 MayJun;50(3):253-62. [PubMed] [Google Scholar]

5. Carbonell X, Chamarro A, Oberst U, Rodrigo B, Prades M. Problematic use of the internet and smartphones in university students: 2006-2017. Int J Environ Res Public Health. 2018 Mar;15(3):475. [PubMed] [Google Scholar]

6. The Vision Council. Eyes overexposed: the digital device dilemma. 2016 Digital Eye Strain Report.

7. Ganne P, Najeeb S, Chaitanya G, Sharma A, Krishnappa NC. Digital eye strain epidemic amid COVID-19 pandemic - a cross-sectional survey. Ophthalmic Epidemiol. 2021 Aug;28(4):285-92. [PubMed] [Google Scholar]

8. Hayes JR, Sheedy JE, Stelmack JA, Heaney CA. Computer use, symptoms, and quality of life. Optom Vis Sci. 2007 Aug;84(8):738-44. [PubMed] [Google Scholar]

9. Hirota M, Uozato H, Kawamorita T, Shibata Y, Yamamoto S. Effect of incomplete blinking on tear film stability. Optom Vis Sci. 2013 Jul;90(7):650-7. [PubMed] [Google Scholar]

10. Kazemi SS, Javanmardi, E, Ghazanfari E. Relationship between general health and musculoskeletal disorders among Tarbiat Modares university students. Int. J. Musculoskelet. Pain. 2017;2(3):287-91. [Google Scholar]

11. Ko P, Mohapatra A, Bailey IL, Sheedy J, Rempel DM. Effect of font size and glare on computer tasks in young and older adults. Optom Vis Sci. 2014 Jun;91(6):682-9. [PubMed] [Google Scholar]

12. Berson D, Dunn FA, Takao M. Phototransduction by retinal ganglion cells that set the circadian clock. Science. 2002 Feb;295(5557):1070-3. [PubMed] 


\section{[Google Scholar]}

13. Lin JB, Gerratt BW, Bassi CJ, Apte RS. Short-wavelength light-blocking eyeglasses attenuate symptoms of eye fatigue. Invest Ophthalmol Vis Sci. 2017 Jan;58(1):4427. [PubMed] [Google Scholar]

14. Loh K, Redd S. Understanding and preventing computer vision syndrome. Malays Fam Physician. 2008 Dec;3(3):128-30. [PubMed] [Google Scholar]

15. Long J, Cheung R, Duong S, Paynter R, Asper L. Viewing distance and eyestrain symptoms with prolonged viewing of smartphones. Clin Exp Optom. 2017 Mar;100(2):133-7. [PubMed] [Google Scholar]

16. Maeda E, Yoshikawa T, Hayashi N, Akai H, Hanaoka S, Sasaki H, Matsuda I, Yoshioka N, Ohtomo K. Radiology reading-caused fatigue and measurement of eye strain with critical flicker fusion frequency. Jpn J Radiol. 2011 Aug;29(7):483-7. [PubMed] [Google Scholar]

17. Misawa TO, Yoshino K, Shigeta S. An experimental study on the duration of a single spell of work on VDT (visual display terminal) performance. Sangyo Igaku. 1984 Jul;26(4):296-302. [PubMed] [Google Scholar]

18. Mohan A, Sen P, Shah C, Jain E, Jain S. Prevalence and risk factor assessment of digital eye strain among children using online e-learning during the COVID-19 pandemic: Digital eye strain among kids (DESK study-1). Indian J Ophthalmol. 2021 Jan;69(1):140-4. [PubMed] [Google Scholar]

19. Moon JH, Kim KW, Moon NJ. Smartphone use is a risk factor for pediatric dry eye disease according to region and age: a case control study. BMC Ophthalmol. 2016 Oct;16(1):188. [PubMed] [Google Scholar]

20. Moon JH, Lee MY, Moon NJ. Association between video display terminal use and dry eye disease in school children. J Pediatr Ophthalmol Strabismus. 2014 MarApr;51(2):87-92. [PubMed] [Google Scholar]

21. Patel S, Henderson R, Bradley L, Galloway B, Hunter L. Effect of visual display unit use on blink rate and tear stability. Optom Vis Sci. 1991 Nov;68(11):888-92. [PubMed] [Google Scholar]

22. Portello JK, Rosenfield M, Chu CA. Blink rate, incomplete blinks and computer vision syndrome. Optom Vis Sci. 2013 May;90(5):482-7. [PubMed] [Google Scholar]

23. Raj $U$, Khare $S$. Indian education system in fight against COVID-19 pandemic. The impact of COVID19 on the international education system. Published: November 19th, 2020. [Google Scholar]

24. Rosenfield M. Computer vision syndrome: a review of ocular causes and potential treatments. Ophthalmic Physiol Opt. 2011 Sep;31(5):502-15. [PubMed] [Google Scholar]

25. Sarwar M, Soomro TR. Impact of smartphone's on society. Eur. J. Sci. Res. 2013;98(2): 216-26. [Google Scholar]
26. Sheppard AL, Wolffsohn JS. Digital eye strain: prevalence, measurement and amelioration. BMJ Open Ophthalmol. 2018 Apr;3(1):e000146. [PubMed] [Google Scholar]

27. Singh HK, Joshi A, Malepati RN, Najeeb S, Balakrishna P, Pannerselvam NK, Singh YK, Ganne P. A survey of E-learning methods in nursing and medical education during COVID-19 pandemic in India. Nurse Educ Today. 2021 Apr;99:104796. [PubMed] [Google Scholar]

28. Teräs M, Suoranta J, Teräs H, Curcher M. Post-Covid-19 education and education technology 'solutionism': A seller's market. Postdigital Science and Education 2020;2:863-78. [Google Scholar]

29. Tosini G, Ferguson I, Tsubota K. Effects of blue light on the circadian system and eye physiology. Mol Vis. 2016 Jan;22:61-72. [PubMed] [Google Scholar]

30. Wong CW, Tsai A, Jonas JB, Ohno-Matsui K, Chen $J$, Ang $M$, Ting DSW. Digital screen time during the COVID-19 pandemic: risk for a further myopia boom? Am J Ophthalmol. 2021 Mar;223:333-7. [PubMed] [Google Scholar] 